\title{
Comparison between Chinese and American Cultures from the Perspective of Consumption View
}

\author{
Lijun Yang \\ School of Business and Trade \\ Huanghe Science and Technology College \\ Zhengzhou, China \\ e-mail:379630960@qq.com
}

\begin{abstract}
Chinese and Americans have significantly different consumption views; from youth, the Americans have been used to consumption by the loan, but most of the Chinese are accustomed to the consumption by the deposit. The US is the biggest consuming country in the world; China is the greatest country of deposit in the world. Different consumption views will have different influences on economic development and the lifestyles of people. The similarities and differences of consumption views are caused by the bilateral culture; different consumption views can reflect different cultures. It is necessary to study the similarities and differences of Chinese and American culture from the consumption perspective. It will be greatly beneficial to the Chinese and American cultural exchanges.
\end{abstract}

Keywords-Consumption view; Chinese and American culture; Comparison

\section{INTRODUCTION}

Before we study this topic, it is necessary for us to understand these following aspects.

This paper has mainly used the following research techniques to analyze the similarities and differences between the Chinese culture and American culture from the aspect of consumption view:

\section{A. Comprehensive Survey Technique.}

The comprehensive survey technique refers to the method of investigation which obtains the related material by adopting many kinds of methods in the marketing activity, thus understands the consumer's psychology, the active characteristics and the general rule indirectly.

\section{B. Interview.}

The interview refers to one research technique from which the surveyor will understand consumer's motive, manner, individuality and value idea and so on through conversation with participants, the oral information's transmission and communication.

\section{Method of Inspection.}

The method of inspection refers to the surveyor observing the consumer's language, behavior, expressions and so on with the goal and plan under the natural condition, and to analyze its intrinsic reason, then to discover the rule of consumer's psychology.

\section{THE ATTITUDE TOWARD CONSUMPTION}

The attitude toward consumption can basically be divided into two kinds of opposite shapes; one is the position of thrift, and the other is the allegation of the expense. Chinese's favorites are saving enough money then buying goods, but Americans are used to expending by lending money.

\section{A. Chinese Universal Consumption View: Consumption by} Saving Money

The house price is too high to be paid by Chinese; they have no choice but choose the method of loan expense. The attitude of consumption most accepted by the Chinese is the expense by saving money. Specifically speaking, it has the following several characteristics.

1) The Chinese regard the material effectiveness, but not the spiritual expense.

"The purpose of one's life is drinking and eating". [1] From this proverb, we can see the characteristics of Chinese attitude toward consumption. The traditional Chinese is quite solid, spending money steadfastly, buying goods and paying attention to the goods reasonable in price. Most of them never buy the thing which has a beautiful appearance but is of no use. Once the Chinese becomes rich, what they first think of is a better meal and a better housing. China has the famous saying named "To be a Happy Person"; that is, controlling the desire from the bottom of the heart and controlling the desire of expense. $^{[2]}$

2) Paying great attention to deposit, industriousness and thriftness. The Chinese are among the nations in the world which pay great attention to deposits in case of the unexpected need for money. The Chinese have one kind of moral outlook; it is generally thought that spending is one kind of ignominious and wasteful behavior, but the industriousness and thrifty are regarded as the noble morals.

3) The ignorant expense accounts for certain proportion (superstition geomancy, qigong, medicine and so on). It is different from the West. China has not formed the bright religious tradition in its history, although external Buddhism and the Taoism have made a profound influence, China truly 
has few followers who believe in these two religions. Chinese ignorance mainly manifests itself in superstition; therefore, many Chinese may spend too much money on superstitious beliefs.

T4) Spending too much on traditional items, for example, on wedding ceremonies, funerals, moving to a new home, giving birth, and so on. Especially in the countryside, the above items are considered traditional etiquette and customs. In recent years, along with the rural economy's development, the farmer also unceasingly increases the amounts spent on wedding and funeral expenses, and they compete to spend with each other on such above expenses. The history and the custom result in this condition. In fact, this kind of abnormal expense has many disadvantages; it not only makes the poor farmer increase his nonessential economic burden, but also makes many bad and negative influences on society.

\section{B. American Consumption View: Consumption by Borrowing Money}

As one of the biggest debtor nations in the world, the US is heavily in debt. The installment payment has created the perfect condition for the American habit of "borrowing money". Certainly, consumption by borrowing money will lead to these conditions: when they are old, they have to sell their houses which belong to them just to escape loneliness or obtain the attendance. Therefore such persons in some sense have never had his or her "own house". In the US, anything can be borrowed. Using the method of installment payment, consumers can not only buy the durable goods, from the expensive electric refrigerator, the color television to the bedding which is cheap enough - you can take away the set of bedspreads with a prepayment of 20-30 dollars, and pay the rest of the money in the following several months, but also can buy an "education".[3] The poor family children may still realize their university dream. One nearly 40 year-old American may still repay the money which he borrowed from the university when he was 20 . He pays no attention to such problems, which is the same as the majority of Americans. He thought that it is no better than the life style to buy all kinds of goods and services without paying cash; he even borrowed money for "pizza" - it is possible to go to the scenic spots and even vacation abroad. The American does not always contribute money naturally; they appear only to know lending and spending the money. "Contingency" is a matter for tomorrow but not today. Therefore it is not necessary to prevent accidents before they occur; it has no value when one has the money in hand. Perhaps the Chinese disposition is inside, but the American's disposition is open. Chinese may live simply and frugally, may endure hardship, may strive for nothing, "never bows because of five buck of rice"; they believe that "gives" and "takes" are better than anything, since they do not have the history and the culture of "refuse to bow",[4] Compared with the Chinese, the Americans like to seek a life of comfort and the satisfaction of desires. Their living is not for the purpose of denying oneself or the reputation which is not worth; they are living the joy from the bottom of their heart. There are many benefits from borrowing money. For example, consumers can enjoy more materials, the business can sell more goods in order to make more money, and finally the entire society can be involved in development.
No wonder that the material of American can be such rich and the American people are envied by the foreigner. They do not come to worry as the things are all "borrowed". Instead they are proud of it as they can enjoy them ahead. After all it is still the Americans who hide behind the wealth. Maybe Americans understand what money is, and know well the philosophy of how to spend it. Perhaps "borrow" is precisely the investment's start; "borrow" must pay the price to return the interest, "borrow" will also bring an unexpected income to the people.

\section{SinO-US CULTURES REFLECTED BY EXPENSE}

The attitude toward consumption is fundamentally the restriction of the state economy level of development; it's also influenced by the income level, the price level, and the population quantity influence. ${ }^{[5]}$

\section{A. Chinese and American Lifestyle Differences Reflected by Material Expense}

The material expense mainly refers to the basic necessities of life. (It includes food, clothes, walking and residence.) The basic necessities of life are the concrete manifestation of the person's lifestyle in each historical period, society's economic development; people's living standard's height can presently come out from the life style.

In the long period of feudal society, as a result of a strict hierarchy, the difference of rank reflects in the difference of life style.

\section{1) Chinese life style reflected by material expense.}

a) Clothes. Looking from the expense characteristic of Chinese, the limitation of the clothing for the Chinese was considered to be the symbol of distinguishing the status of one kind in the Qing Dynasty. The common people can only put on the thick cotton garment, so "the cotton garment" has become the symptom of the common people. The official and the rich disdained the cotton garment. This kind of old habit has continued for several thousands of years. Until the 20th century, along with economical development, although peoples' clothing has had a huge change, the cotton fabric was still not in vogue; this is concerned with the clothing tradition.

b) Food. In the feudal society, the emperor, the feudal lord, the minister, the doctor and the gentleman ate meat, but the common people ate vegetables. From the beginning of the 20th Century, although the rank system was eliminated, because the national economy was still far behind the normal level, it was still a Chinese farmer's biggest ideal to get enough food and clothes for the several thousands of years. After the reform and open policy, China's culture of food had a vigorous development. But it is still recognized in China that food is everything for the people.

c) Residence. In the feudal ranking of society, Chinese houses' expense status was different from the status of people. Although in the $20^{\text {th }}$ Century, our country's city and countryside housing conditions have made a very big improvement, it still could not compare with the world of developed countries, particularly the draggle of sanitation facility, which needs to be improved. They are not willing to suffer unexpected financial losses and are quite conservative; 
therefore China's typical house is the "pen type", not the Western open style.

d) Walking. In ancient times, hundred of officials often rode horses. There was a great difference in the number and color of their horses; it was the symbols of the different status for the different riders. [6] Today, China's transportation vehicles are more convenient than before.

\section{2) American lifestyle reflected by material expense.}

a) Clothes. Some people said that American economy is established above the "expense", but not the "storage". American culture is the typical expenditure culture. Although America has experienced the serious economic recession since the 70s, they own the most formidable economic potentiality in the world; that can be seen from the American lifestyle. Although the US work force is productive and the modernization level is high, all the people in the street wear cotton and kapok products. In the 20th Century, as American quality of life improved greatly, clothes' personalization has become an outstanding feature, and the total trend is the diversification and personalized evolution. The American pursues happy novelty, likes proposing something new and different, especially the young people.

b) Food. The American conception of eating is different from the Chinese. In America, food materials are quite rich; there hasn't been a problem for a long time with the food supply. As long as he or she is an American citizen, lives below the low-income level, and has been unemployed temporarily, they can apply for relief to the US government. Meals are not the most major problem that people cared about. Americans pay more attention to the following aspects: nutrition, clean, and convenient. Americans study many vegetables' nutrition ingredient of each food; for example which kind of food will put on weight; which negative consequence will be caused; which kind of food can cause the skin lubrication, gloss etc. In addition, the Americans use the individual dining system. They will clamp the vegetable in their own trays even when they have the Chinese meal. If they eat in the restaurant, it is common for them to carry off the rest of the food; it is considered not moral to leave food remaining. The American diet in the 20th Century pays great attention to the efficiency and convenience. As an adaptation to the modern rhythms of a quick life and work, the fast food industry has emerged as a catering business revolution.

c) Residence. American is also fastidious about the housing conditions. Their housing conditions have different standards. Generally a couple must have a bedroom and a living room, of course, with the kitchen and the bathroom. Three-year-old children will have an independent room. As for the rich person's area, it is very common for the old man to live in 200 square meters and in small foreign-style multi-storied buildings. In the $20^{\text {th }}$ Century, after basic solution of accommodation, people's attention is changed to the beautification of living conditions, the interior decorations, and the environment beautification.

d) Walking. Nearly each family has a vehicle, the roads are good, and the superhighways extends in all directions likes a net which means you can go anywhere easily. The US has the long-distance bus which can run everywhere; there are many railroads, and you can have a seat without ordering a ticket ahead of time. There are also the developed aviation industry and over ten thousand nation's airports; you just need to make a call before you buy the airplane ticket. The telecommunication industry is also very developed. The automobile is one of important material civilization symbols in $20^{\text {th }}$ Century. The automobile's development has formed an automobile culture. It is not only the transportation vehicle, but also a symbol of the status. The American displays unusual enthusiasm and love for the automobile. The automobile has changed the people's life and become the freedom and independence symbol of the young people. It has picked up people's rhythm of life and remolded the people's space and time conception. The automobile increased American's fluidity, thus the US has become one "to lie down on the automobile wheel's country". ${ }^{[7]}$

\section{B. Chinese and American Lifestyle Differences Reflected in Spiritual Expense}

Spiritual expense pursues invisible human labor achievements, like brand information. Chinese have experienced so many years of closing the borders and practicing isolationism that they became a little narcissistic. When the border was broken by westerners, the Chinese suddenly awakened and realized that the big disparity compared to the west. China's science and technology fell behind; Chinese spiritual expense also lagged when compared to America. The ideological difference between Chinese and American is that the Chinese ideological mode is vivid, directviewing and synthetic; the American is individual, abstract and unique.[8] From these philosophies, the difference between China and US mainly manifests itself in the dialectical thinking and the logical thinking. Chinese dialectical thought is contains several principles: The change, contradictory, and neutral theory. The change theory says that the world is continually changing; there are no eternal rights and wrongs. The contradiction theory believes that all things have a contradictory entity with the opposite constitution. Neutral theory manifests itself in the Golden Mean, believing that anything has a moderate rationality. In China, the "Golden Mean" has passed several thousand years of history and formed its own disposition characteristic. This can be seen from the Chinese film expense. Chinese movies, particularly the big piece directed by the big director, favor the costume movie, like "Hiding Everywhere", "Chi Bi", and so on, but very few science fiction films. However, the big pieces of the American movies mostly are science fiction films, like "Day After Tomorrow". Chinese directors should not be short of money, but it is mainly because they have less of the US's thinking mode: Existence is reasonable; they may not need to make too much consideration about the future. American thought is one of logical thinking. It emphasizes world identity, noncontradiction, and the role of neutrality. The identity believes that the essence of a matter will not change, the noncontradiction refers to a proposition as impossible right or wrong; rows of neutrality stresses a thing is either right or wrong, without any intersects.[9] American's thinking mode also calls the analysis thought but not the Chinese concept of pursuing compromise and harmony. They like to separate parts 
from the whole, and carry on the logic analysis of the essential characteristic of things.

\section{Chinese and American National Disposition Reflected by Patterns of Consumption}

The disposition of a nationality, that is, the nation's common psychological quality, is a national culture characteristic psychology which formed on the basis of various nationalities and the process of the development. The Chinese nation and the America nation are considered two great nations in the world; the common characteristics between them are: industrious, brave, warm, and positive enterprising. However there exists differences in the Sino-US national disposition, which is considered an important component of the difference between China and the US.

Viewed from the Chinese saving money for the expenses, Chinese regard more group consciousness, and pay greater attention to the overall value. Individuals should make a contribution to the family, the descendants, and the whole society; personal interest should obey the community benefit, and the community benefit should be higher than the individual benefit. Therefore, it has then formed the conception of the traditional public and private rights. All the while, Chinese have thought much of the righteousness and make light of the benefit; they despise the personal interest and emphasize the community benefit. Therefore, even if the Chinese borrow money to expand, the majority will try their best to return the money. Owing money to the expense without giving back will earn contempt in China. It's their obligation and mission to contribute to their family, the society and the nationality. But overemphasizing the group consciousness will result in neglecting the person's individual development, constraining the freedom of the individual's independence and individuality.

Looking from the American owing money for the expense, what the Americans stress is individual consciousness. They pay great attention to the individual's value. US individualism is displayed as follows: Pursuing individual freedom, independence, freedom of consideration, and the choice itself. So long as it does not surpass the legal scope, no one has the right to interfere with others. [10] There is obvious superiority; it makes the American be more democratic and equal, and even the parents have no rights to determine anything about their children. It also results in that young American are accustomed to struggle depending upon their own strength, to strive for the survival and the development independently without relying on their parents or their family: But this thought does not attach to the family responsibility and duty, but causes the entire society to park a indifferent human sentiment environment. They consider profit more than sentiment.

\section{CONCLUSION}

The American loan crisis has caused the global financial crisis, and has caused the economic growth rate of the world to suspend or stagnate. American consumption by borrowing money accelerates the deterioration of the loan crisis to a great extent; but Chinese consumption by saving money reduces the bad influence of the financial crisis on the Chinese economy to a great extent. This article makes the analysis from the consumption view, and it may facilitate Chinese and American communication. This article summarizes the main characteristics of the Chinese and American cultures demonstrated by the consumption view: material expense reflects Chinese and American lifestyle differences; spiritual expense reflects Chinese and American thinking mode differences; consumption styles reflects the Chinese and American national dispositions. We may discover that both countries' cultures create the different consumption views and the different performances. It is not difficult for us to draw the following conclusions: To analyze the Chinese and American cultures from the aspect of the consumption view has contributed to further understanding the formation of economical and the social phenomena. We should use historical dialectical materialism to analyze the Chinese culture and American culture. Through this analysis, we can better avoid the cultural conflicts and communicate successfully with each other in the Trans-Culture social intercourse.

\section{ACKNOWLEDGMENT}

I would like to give my heartfelt thanks to many people for their help in my academic studies over the past years.

My deepest gratitude to my family, thanks for their kindness, patience, encouragement. Thanks to my school that has given me this delicious opportunity. And thanks to my dear friends who have given their great help to me in my research.

\section{REFERENCES}

[1] Botempo, R. N., Bottom, W.P., \& Weber. E.U. Cross-cultural Differences in Risk Perception: A Model Based Approach [J]. Risk Analysis, 1997, 17(4): 479.

[2] Brislin, R.W. \&Baumgartner, S. R. Non-random Sampling of Individuals in Cross-cultural Research [J]. Journal of Cross-Cultural Psychology, 1998, 2(4): 397.

[3] Cerill, G.W. Chinese and American Consumption and Culture [J]. Journal of Cross-Cultural Psychology, 1998, 2(4): 401

[4] Hofstede, G. Culture's Consequence [M]. Beverly Hill, CA: Sage, 1999.

[5] Hofstede, G. Cultures and Organizations: Software of the Mind[M]. London: McGraw-Hill, 2001.

[6] Radford, M.H., Mann, L., Ohta, Y.\& Nakane, Y. Differences between Australian and Japanese Students in Reported Use of Decision Process [J]. International Journal of Psychology. 2001, 26(1): 34.

[7] Radford, M.H., Mann, L., Ohta, Y.\& Nakane, Y. Differences between Australian and Japanese Students in Decision Self-esteem, Decisional Stress, and Coping Style [J]. Stephen, M.N. Journal of Cross-Cultural Psychology, 1993, 24(3): 285.

[8] Taylor, S.\& Todd, P. Decomposition and Crossover Effects in the Theory of Planned Behavior: A Study of Consumer Adoption Intensions[J]. International Journal of Research in Marketing, 1995, 19(2): 234.

[9] Tally, P. American and Chinese Culture [J]. International Journal of Research in Marketing, 2006,11(3): 18.

[10] Taylor, S.\& Todd, P. Understanding Information Technology Usage: A Test of Competing Models[J]. Information Systems Research. 1995, 6(2): 146. 